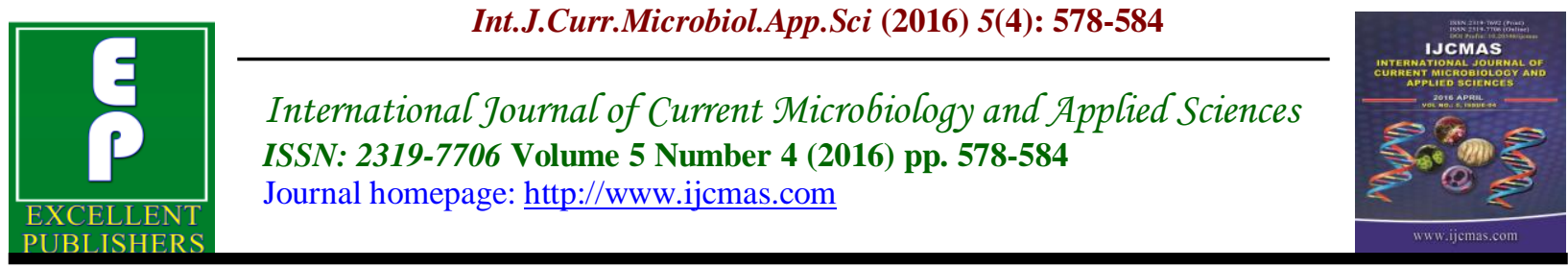

Original Research Article

http://dx.doi.org/10.20546/ijcmas.2016.504.065

\title{
Antibacterial Activity of Verbascum chinense (Scrophulariaceae) Extracts
}

\author{
Virender Kaur $^{1 *}$ and Kumud Upadhyaya ${ }^{2}$ \\ ${ }^{1}$ NIMS University, Jaipur, India \\ ${ }^{2}$ Department of Pharmaceutical Sciences, Kumaun University, Nainital, India \\ *Corresponding author
}

\begin{abstract}
A B S T R A C T
Keywords

Antibacterial, total phenols, Gram positive, Gram negative, flavonoids Verbascum chinense.

\section{Article Info}

Accepted:

19 March 2016

Available Online:

10 April 2016

The aim of the study was to screen the antibacterial activity and phytochemical analysis of various extracts of Verbascum chinense a member of Scrophulariaceae family. The antibacterial activity of various extracts of $V$. chinense was determined with agar-well diffusion method. The results provide evidence that the extracts of $V$. chinense contained glycosides, flavonoids, saponins and phenolic compounds which may be responsible for the substantial antibacterial activity. Among different solvent extract, chloroform and n-butanol extracts exhibited a broad spectrum of antimicrobial activity. It showed strong antibacterial activity against Gram positive bacterial strain like Klebsiella pneumoniae, Bacillus subtilis and Gram negative strains like Escherichia coli. The ethanolic and ethyl acetate extract showed low antibacterial activity against the bacterial strains. The study ascertains the value of plants used in Ayurveda, which could be of considerable interest to the development of new drugs, to supports there is scientific basis of their utilization in traditional medicinal for wound healing and also in treatment of some infectious diseases.
\end{abstract}

\section{Introduction}

Multidrug-resistant bacterial infections are an increasing problem due to the emergence and propagation of microbial drug resistance and the lack of development of new antimicrobials. Discovery of Antibiotic by Traditional means have failed to keep pace with the evolution of resistance. Therefore, there is an increasing demand to develop new strategies to control bacterial infections. Plant phytochemicals have already shown their potential as antibacterials when used alone and as synergists or potentiators of other antibacterial agents. The use of phytochemical products and plant extracts as resistance-modifying agents (RMAs) represents an increasingly active research topic. A mechanism of action of these phytochemicals is different than conventional antibiotics and could, therefore be useful in the treatment of resistant bacteria. The therapeutic potential of these products, however, remains to be clinically proven (Abreu et al., 2012).

Antibiotics are naturally occurring or synthetic organic compounds which inhibit or kill selective bacteria, generally at low concentration. The increase in resistance to 
microorganisms due to indiscriminate use of antimicrobial drugs forced scientists to search for new antimicrobial substances from various sources including medicinal plants. It is estimated that local communities have used about $10 \%$ of all flowering plants on Earth to treat various infections, although only $1 \%$ have gained recognition by modern scientists (Gupta and Pandey, 2014).

Verbascum chinense is traditionally used as sedative, astringent, febrifuge, and for skin eruptions (Medicinal Plants of South Western Maharastra; Cowan, 1999). V. chinense extracts are used among the local people for the purpose of remedy, yet no scientific study showing the potential of this species as an antibacterial agent. Therefore, the purpose of the current study is to investigate the antimicrobial activity of the various extracts of $V$. chinense.

\section{Materials and Methods}

\section{Collection of Plant Material and Preparation of Extracts}

The required plant material Verbascum chinense leaves were obtained from Nainital region in the month of April and was identified and authenticated by Principal Scientist, National Bureau of Plant Genetic Resources Regional Station, (N.B.P.G.R) Niglat, Uttarakhnad. The specimen has been deposited in Herbarium at N.B.P.G.R. with accession number VK-03. The powdered material after defatting with petroleum ether was separately extracted in a Soxhlet apparatus with, chloroform, ethyl acetate, nbutanol, and ethanol.

\section{Phytochemical Analysis}

Phytochemical studies were carried out for chloroform, ethyl acetate, n-butanol, ethanol of Verbascum chinense leaves to detect the presence of different phytochemicals such as glycosides, flavonoids, saponins and phenolic compounds, sterols, saponins, carbohydrates, amino acis, proteins by using standard procedures (Trease and Evans, 1978; Harborne).

\section{Screening of Antibacterial Activity}

\section{Test Microorganisms}

Five different bacterial strains were used in this antibacterial activity analysis. The bacterial strains used were obtained from M.T.C.C., IMTECH Chandigarh. For the purpose of antimicrobial evaluation five microorganisms, Escherichia coli (M.T.C.C. No.443),Pseudomonas aeroginosa (M.T.C.C. No. 424), Bacillus subtilis (M.T.C.C. No. 441), Klebsiella pneumoniae(M.T.C.C. No3384), Salmonella typhimurium (M.T.C.C. No. 3224) were purchased. For Salmonella typhimurium tripticase soy agar was used as nutrient medium. For remaining bacterial strains nutrient agar was used. The bacterial cultures purified and stored at $4^{\circ} \mathrm{C}$.

\section{Antimicrobial Assay}

Antimicrobial activities of different extracts were evaluated by the agar well diffusion method (Murray et al.) (1995) modified by (Olurinola) (1996). The bacterial assay was performed by agar well diffusion method. Stock solution of each plant extract was prepared at a concentration of $1 \mathrm{mg} / \mathrm{ml}$ in different plant extacts viz. Ethanol, Chloroform, Ethyl Acetate And n-Butanol. Different concentrations of plant solvent extracts $(10,20,30,40,50,60 \mu \mathrm{g} / \mathrm{ml})$ were added into the wells were added into the wells and allowed to diffuse at room temperature for $2 \mathrm{hrs}$. The plates were incubated at $37^{\circ} \mathrm{C}$ for $18-24 \mathrm{~h}$ for bacterial pathogens Then the plates were incubated 
over night at $37^{\circ} \mathrm{C}$. The bacterial growth was determined by measuring the diameter of the zone of inhibition. The experiment was duplicated three times and the mean \pm standard deviation values were recorded.

\section{Standard Drug}

Gentamicin $(10 \mu \mathrm{g} / \mathrm{ml})$ was used as standard drug against all the strains. Gentamicin was used as a positive control.

\section{Results and Discussion}

\section{Qualitative Phytochemical Screening of Verbascum chinense}

Qualitative phytochemical screening of Verbascum chinense revealed the presence of different phytochemical constituents like steroids, terpenoids, flavonoids, glycosides, phenols, terpenoids, saponins, carbohydrates. The extracts gave negative results for amino acids, proteins, alkaloids, oils.

\section{Qualitative Phytochemical Screening of Verbascum chinense}

Plant products have been shown to have fewer side effects, good therapeutic potential, due to the presence of active pharmacologically important substances, such as terpenes, alkaloids, flavonoids and glycosides (Patel Rakesh and Patel Kiran, 2004; Yusuf et al., 2002).

Qualitative Phytochemical screening of Verbascum chinense extracts confirmed the presence of different phytochemical constituents like flavonoids, glycosides, saponins, carbohydrates, phenols, steroids. The extracts gave negative results for the amino acids, alkaloida, and oils. The results are given in Table 1.

\section{In vitro Antimicrobial Activity}

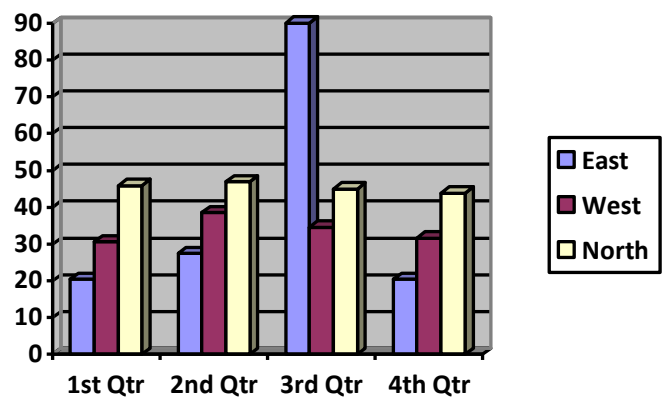

The potential for developing antimicrobials from higher plants appears rewarding as it will lead to the development of a phyto medicine to act against microbes. Plantbased antimicrobials have enormous therapeutic potential as they can serve the purpose with lesser side effects that are often associated with synthetic antimicrobials. Continued further exploration of plant-derived antimicrobials is needed today (Farrukh and Ahamed, 2003).

In the present investigation, different extracts of Verbascum chinense was evaluated for exploration of their antimicrobial activity against certain Gram negative and Gram positive bacteria at different concentrations, i.e., 10, 20, 30, 40, $50,60 \mu \mathrm{g} / \mathrm{ml}$ by measuring the diameter of zone of growth inhibition against different micro-organism using gentamycin as standard. The different extracts of Verbascum chinense inhibit the growth of tested micro-organism (Table 2, 3, 4, 5) respectively. The n-butanol extract of Verbascum chinense was active against all bacterial strains at different concentrations of extract with exception of Pseudomonas aeruginosa Maximum effect was observed at a dose of $60 \mu \mathrm{g} / \mathrm{ml}$ for Bacillus subtilis 
Table.1 The Secondary Metabolites Present in Different Extracts V. chinense

\begin{tabular}{|c|c|c|c|c|}
\hline \multirow[b]{2}{*}{$\begin{array}{l}\text { Phytochemical } \\
\text { constituents }\end{array}$} & \multicolumn{4}{|c|}{ Verbascum chinense } \\
\hline & $\begin{array}{c}\text { Ethanolic } \\
\text { extract }\end{array}$ & $\begin{array}{c}\text { Chloroform } \\
\text { extract }\end{array}$ & $\begin{array}{c}\text { Ethyl acetate } \\
\text { extract }\end{array}$ & $\begin{array}{c}\text { n-Butanol } \\
\text { extract }\end{array}$ \\
\hline Carbohydrates & + & - & + & + \\
\hline Glycosides & + & + & + & + \\
\hline Steroids & + & + & + & + \\
\hline $\begin{array}{l}\text { Protein and } \\
\text { Amino acids }\end{array}$ & - & - & - & - \\
\hline Saponins & + & _ & + & + \\
\hline Flavonoids & + & + & + & + \\
\hline Alkaloids & _ & _ & _ & - \\
\hline Oils & _ & - & - & - \\
\hline Phenols & + & + & + & + \\
\hline Terpenoids & + & - & + & + \\
\hline
\end{tabular}

Table.2 Different Bacterial Strains Showing the Zone of Inhibition for VCBU Extract

\begin{tabular}{|c|c|c|c|c|c|c|c|}
\hline $\begin{array}{c}\text { MICRO- } \\
\text { ORGANISM }\end{array}$ & & & THE ZONE OF & HIBITION FOR & SUU EXTRACT & & \\
\hline $\begin{array}{l}\text { Bacterial } \\
\text { Strain }\end{array}$ & Gentamycin & $\mathbf{1 0} \mu \mathrm{g} / \mathrm{ml}$ & $\mathbf{2 0} \mu \mathrm{g} / \mathbf{m l}$ & $\mathbf{3 0} \mu \mathrm{g} / \mathbf{m l}$ & $40 \mu \mathrm{g} / \mathbf{m l}$ & $\mathbf{5 0} \mu \mathrm{g} / \mathbf{m l}$ & $\mathbf{6 0} \mu \mathrm{g} / \mathbf{m l}$ \\
\hline $\begin{array}{c}\text { Escherichia } \\
\text { coli }\end{array}$ & $24.933 \pm 0.0577 \mathrm{~mm}$ & - & $3.966 \pm 0.0557 \mathrm{~mm}$ & - & - & - & - \\
\hline $\begin{array}{c}\text { Pseudomonas } \\
\text { aeruginosa }\end{array}$ & $20.966 \pm 0.0577 \mathrm{~mm}$ & - & - & - & - & - & - \\
\hline $\begin{array}{c}\text { Bacillus } \\
\text { subtilis }\end{array}$ & $19.933 \pm 0.0577 \mathrm{~mm}$ & $3.86 \pm 0.152 \mathrm{~mm}$ & $2.633 \pm 1.184 \mathrm{~mm}$ & $2.667 \pm 0.577 \mathrm{~mm}$ & $3.667 \pm 0.577 \mathrm{~mm}$ & $5.933 \pm 0.11547 \mathrm{~mm}$ & $6.9 \pm 0.1 \mathrm{~mm}$ \\
\hline $\begin{array}{c}\text { Klebsiela } \\
\text { pneumonia }\end{array}$ & $24.9 \pm 0.1 \mathrm{~mm}$ & - & $2.0 \pm 0.00 \mathrm{~mm}$ & - & - & - & - \\
\hline $\begin{array}{l}\text { Salmonella } \\
\text { typhimurium }\end{array}$ & $18 \pm 0.1 \mathrm{~mm}$ & - & $1.9 \pm 0.173 \mathrm{~mm}$ & - & - & - & - \\
\hline
\end{tabular}


Table.3 Different Bacterial Strains Showing the Zone of Inhibition for VCCH Extract

\begin{tabular}{|l|c|c|c|c|c|c|c|}
\hline Microorganism & \multicolumn{5}{|c|}{ THE ZONE OF INHIBITION FOR VCCH EXTRACT } \\
\hline $\begin{array}{l}\text { Bacterial } \\
\text { Strain }\end{array}$ & Gentamycin & $\mathbf{1 0} \mu \mathrm{g} / \mathbf{m l}$ & $\mathbf{2 0} \mu \mathrm{g} / \mathbf{m l}$ & $\mathbf{3 0} \mu \mathrm{g} / \mathrm{ml}$ & $\mathbf{4 0} \mu \mathrm{g} / \mathbf{m l}$ & $\mathbf{5 0} \mu \mathrm{g} / \mathbf{m l}$ & $\mathbf{6 0} \mu \mathrm{g} / \mathbf{m l}$ \\
\hline Escherichia coli & $24.933 \pm 0.0577 \mathrm{~mm}$ & $4.9 \pm 0.1 \mathrm{~mm}$ & $3.967 \pm 0.0577 \mathrm{~mm}$ & $2.9 \pm 0.1 \mathrm{~mm}$ & $2.9 \pm 0.1 \mathrm{~mm}$ & $2.9 \pm 0.1 \mathrm{~mm}$ & - \\
\hline $\begin{array}{c}\text { Pseudomonas } \\
\text { aeruginosa }\end{array}$ & $20.966 \pm 0.0577 \mathrm{~mm}$ & - & - & - & - & - \\
\hline Bacillus subtilis & $19.933 \pm 0.0577 \mathrm{~mm}$ & $1.9667 \pm 0.0577 \mathrm{~mm}$ & $2.867 \pm 0.1527 \mathrm{~mm}$ & - & - & $6.967 \pm 0.1 \mathrm{~mm}$ & $16.933 \pm 0.1154 \mathrm{~mm}$ \\
\hline $\begin{array}{c}\text { Klebsiela } \\
\text { pneumonia }\end{array}$ & $24.9 \pm 0.1 \mathrm{~mm}$ & $5.0 \pm 0.0 \mathrm{~mm}$ & $5.933 \pm 0.11547 \mathrm{~mm}$ & $7.966 \pm 0.0577 \mathrm{~mm}$ & $11 \pm 0.0 \mathrm{~mm}$ & $16.933 \pm 0.1154 \mathrm{~mm}$ & $21.933 \pm 0.1154 \mathrm{~mm}$ \\
\hline $\begin{array}{c}\text { Salmonella } \\
\text { typhimurium }\end{array}$ & $18 \pm 0.1 \mathrm{~mm}$ & - & $3.667 \pm 0.5773 \mathrm{~mm}$ & $2.966 \pm 0.0577 \mathrm{~mm}$ & $1.9667 \pm 0.0577 \mathrm{~mm}$ & $13.9667 \pm 0.0577 \mathrm{~mm}$ & $18.9667 \pm 0.0577 \mathrm{~mm}$ \\
\hline
\end{tabular}

Table.4 Different Bacterial Strains Showing the Zone of Inhibition for VCET Extract

\begin{tabular}{|c|c|c|c|c|c|c|c|}
\hline Micro-Organism & \multicolumn{7}{|c|}{ THE ZONE OF INHIBITION FOR VC ET EXTRACT } \\
\hline Bacterial Strain & Gentamycin & $\mathbf{1 0} \mu \mathrm{g} / \mathbf{m l}$ & $20 \mu \mathrm{g} / \mathbf{m l}$ & $\mathbf{3 0} \mu \mathrm{g} / \mathbf{m l}$ & $40 \mu \mathrm{g} / \mathrm{ml}$ & $\mathbf{5 0} \mu \mathrm{g} / \mathbf{m l}$ & $60 \mu \mathrm{g} / \mathbf{m l}$ \\
\hline Escherichia coli & $24.933 \pm 0.0577 \mathrm{~mm}$ & $3.966 \pm 0.0577 \mathrm{~mm}$ & - & - & - & - & - \\
\hline Pseudomonas aeruginosa & $20.966 \pm 0.0577 \mathrm{~mm}$ & $4.0 \pm 0.00 \mathrm{~mm}$ & $6.9 \pm 0.1 \mathrm{~mm}$ & $6.933 \pm 0.11547 \mathrm{~mm}$ & - & - & - \\
\hline Bacillus subtilis & $19.933 \pm 0.0577 \mathrm{~mm}$ & $3.933 \pm 0.1154 \mathrm{~mm}$ & - & - & - & - & - \\
\hline Klebsiela pneumonia & $24.9 \pm 0.1 \mathrm{~mm}$ & $1.9667 \pm 0.0577 \mathrm{~mm}$ & $2.933 \pm 0.1154 \mathrm{~mm}$ & - & - & - & - \\
\hline Salmonella typhimurium & $18 \pm 0.1 \mathrm{~mm}$ & $3.9 \pm 0.1 \mathrm{~mm}$ & - & - & - & - & - \\
\hline
\end{tabular}

Table.5 Different Bacterial Strains Showing the Zone of Inhibition for VCEA Extract

\begin{tabular}{|c|c|c|c|c|c|c|c|}
\hline MICRO-ORGANISM & \multicolumn{7}{|c|}{ THE ZONE OF INHIBITION FOR VC EA EXTRACT } \\
\hline Bacterial Strain & Gentamycin & $\mathbf{1 0} \mu \mathrm{g} / \mathrm{ml}$ & $20 \mu \mathrm{g} / \mathrm{ml}$ & $30 \mu \mathrm{g} / \mathbf{m l}$ & $40 \mu \mathrm{g} / \mathrm{ml}$ & $\mathbf{5 0} \mu \mathrm{g} / \mathbf{m l}$ & $60 \mu \mathrm{g} / \mathrm{ml}$ \\
\hline Escherichia coli & $24.933 \pm 0.0577 \mathrm{~mm}$ & - & - & - & - & - & - \\
\hline Pseudomonas aeruginosa & $20.966 \pm 0.0577 \mathrm{~mm}$ & - & - & - & - & - & - \\
\hline Bacillus subtilis & $19.933 \pm 0.0577 \mathrm{~mm}$ & - & - & $6.9 \pm 0.1 \mathrm{~mm}$ & $221.9 \pm 0.1 \mathrm{~mm}$ & - & - \\
\hline Klebsiela pneumonia & $24.9 \pm 0.1 \mathrm{~mm}$ & - & - & - & - & - & - \\
\hline Salmonella typhimurium & $18 \pm 0.1 \mathrm{~mm}$ & - & - & - & - & - & - \\
\hline
\end{tabular}


The chloroform extract was active against all bacterial strains at different concentrations of extract with exception of Pseudomonas aeruginosa. The chloroform extract exhibited maximum zone of inhibition against Klebsiella pneumoniae, Salmonella typhimurium, and Bacillus subtilis in dose dependent manner. However the inhibitory effect was not found to be concentration dependent against Escherichia coli. A biphasic effect i.e. inhibitory effect decreased when the concentration of the samples was increased in assay mixture.

The ethanol extract of Verbascum chinense was active against all bacterial strains. The concentration dependent inhibitory effect was observed only against bacterial strain i.e. Pseudomonas aeruginosa. However there was no zone of inhibition observed against all bacterial strains when the concentrations of samples were increased in assay mixture.

The ethyl acetate extract showed minimum inhibitory effect against bacterial strains. However the extract showed some inhibitory effect against Bacillus subtilus at concentration of $30 \mu \mathrm{g} / \mathrm{ml}$ and $40 \mu \mathrm{g} / \mathrm{ml}$.

The antimicrobial activity of Verbascum chinense suggests that the extract contain the effective active phytochemicals responsible for the elimination of microorganisms. The antimicrobial potency of plants is believed to be due to saponins, phenolic compounds, essential oils and flavonoids as secondary metabolites (Avinash et al., 2011). It has been proposed that the mechanism of the antimicrobial effects involves the inhibition of various cellular processes, followed by an increase in plasma membrane permeability and finally, ion leakage from the cells (Kumar et al., 2006). The ascending sequence of maximum antimicrobial activity against test microorganisms were as follows: chloroform extract $>$ n-butanol extract> ethanol extract > ethyl acetate extract shown in (Table 3, 4, 5, 6). The study ascertains the value of plants used in Ayurveda and herbal practice could be of considerable interest to the development of new drugs but medicinal plants can be poisonous if wrong plant parts or wrong concentrations are used (Ewing and Martin, 1974). Herbal medicines are assumed to be harmless. Study is in progress to further evaluate the mechanisms of action of these active test extracts on test organisms associated with certain human diseases (Frohne, 1999).

In conclusion, the result of the study revealed the presence of various secondary metabolites in the stem bark extracts of Verbascum chinense, which may be responsible for the antimicrobial efficacy of this medicinal plant. The results of the study are very encouraging and indicate that this plant should be more extensively studied to explore its potential in the treatment of many infectious diseases. Further investigation is needed to determine the actual chemical structure of the active compounds.

\section{References}

Abreu, Cristina, A., McBain, J., Simões, M. 2012. Nat. Prod. Rep., 29: 1007-1021. Avinash, P., Idress, H., Attitalla, M., Ramgopal, C.H., Santhosh, Balaji, M. 2011. In vitro antimicrobial and antioxidant activities of bark extracts of Bauhinia purpurea, African $J$. Biotechnol., 10(45): 9160-9164.

Cowan, M.M. 1999. Plant products as antimicrobial agents. Clin Microbiol., 12(4): 564-82.

Ewing, H., Martin, J. 1974. Enterobacteriaceae. In Manual of clinical microbiology, 2nd Ed., Edited 
by E. H. Lennette, E. H. Spaulding and J. P. Truant, Washington. 109.

Farrukh, A., Ahamed, I. 2003. Broad spectrum antibacterial and antifungal property of certain traditionally used Indian medicinal plants. World $J$. Microbiol. Biotechnol., 19: 63-657.

Frohne, D. 1999. Plant intoxicants - is there a risk from herbal preparation, $J$. Phytother., 20: 201-202.

Gupta, A., Pandey, V.N. 2014. Herbal Remedies of Aquatic Macrophytes of Gorakhpur District, Uttar Pradesh (India) Int. J. Pharm. Bio. Sci., 5(1): 300-308.

Harborne, J.B. Phytochemical Methods: A Guide to Modern Technique of Plant Analysis.3rd Ed. London, England: Chapman and Hall, 114-118.

Kumar, V.P., Neelam, S.C., Harish, P. 2006. Search for antibacterial and antifungal agents from selected Indian medicinal plants, J. Ethopharmacol., 107: 182188.
Medicinal Plants of South Western Maharastra, Biodiversity in India, Vol. 4: 326-29.

Murray, P.R., Baron, E.J., Pfaller, M.A., Tenover, F.C., Yolken, H.R., 1998. Manual of Clinical Microbiology, 6th Ed. ASM Press, Washington DC, 1518.

Olurinola, P.F. 1996. A laboratory manual of Pharmaceutical Microbiology, Idu, Abuja, Nigeria, 69-105.

Patel Rakesh, J., Patel Kiran. 2004. J. Experimental Microbiol., Aditya Publication Gujarat India, 1, No. 3.

Trease, E.G., Evans, W.C. 1978. Pharmacognosy, 11th Edition, Balliere Tindall, London. 115-222.

Yusuf, A.J., Hana, S., Abdu, S. 2002. Antimycotic activities of selected plant flora growing wild in Lebanon against phytopathogenic fungi. J. Agri. Food Chem., 50: 3208-3213.

\section{How to cite this article:}

Virender Kaur and Kumud Upadhyaya. 2016. Antibacterial Activity of Verbascum chinense (Scrophulariaceae) Extracts. Int.J.Curr.Microbiol.App.Sci.5(4): 578-584. doi: http://dx.doi.org/10.20546/ijcmas.2016.504.064 